\title{
Antibiotic Encapsulated Nanomaterials with Application in Medical Area
}

\author{
ALINA COSTINA LUCA ${ }^{1}$, LETITIA DOINA DUCEAC 2*, GETA MITREA3*, MADALINA IRINA CIUHODARU1, \\ DANIELA LUMINITA ICHIM ${ }^{2}$, GINEL BACIU33, ELENA ARIELA BANU ${ }^{3}$, ALIN CONSTANTIN IORDACHE ${ }^{3}$ \\ ${ }^{1}$ Grigore T. Popa University of Medicine and Pharmacy, Faculty of Medicine, 16 Universitatii Str., 700115, lasi, Romania \\ ${ }^{2}$ Apollonia University of Iasi, Faculty of Medicine, Academician Ioan Haulica Institute of Researches, 2 Muzicii Str., 700399, Iasi, \\ Romania \\ 3University Dunarea de J os Faculty of Medicine and Pharmacy, 47 Domneasca Str., 800008,Galati, Romania
}

\begin{abstract}
Novel materials belonging to the class of anionic clays are synthesized by investigating their properties at nano scale. Thus, hydrotalcites or layered double hydroxides (LDHs) were used as drug delivery carriers in order to prevent or to treat infections produced by some pathogen agents. Their physical and chemical properties allow them to include different molecules in the interlayer space and then to ensure their transport to the target. The current work reveals the obtaining of nanohybrid compounds type amoxicillin/clavulanic acid-layered double hydroxides (Amox/CA-LDHs) followed by structural and morphological characterization of these nanostructures for future applications as drug controlled release systems. IR spectroscopy and Scanning Electron Microscopy pointed out LDHs ability to incorporate the medicines without modification of therapeutic activity.
\end{abstract}

Keywords: antibiotic, layered double hydroxides (LDHs), drug delivery, IR spectroscopy, medical area

Anionic clays or hydrotalcite-like nanomaterials, also known as layered double hydroxides (LDHs) are constituted by positively charged layers of hydroxides of divalent and trivalent metal cations counterbalanced by negatively charged anions. The most interesting feature of these nanostructures is the facility to replace the existing anions between sheets with a wide variety of molecules making them applicable in different fields, especially medicine [1-4].

Another important property consist in possibility of vary the ratio and the type of divalent and trivalent cations and the type of anion in the interlayer gallery respectively. Furthermore, one of the most interesting features of these nanocompounds is the obtaining of LDHs nanoarchitectures with controllable properties [5-9]. Figure 1 present the LDHs-like structure where the interlayer space of the nanomaterial is occupied with anions and water molecules.

A particular property of LDHs nanostructures is their ability to encapsulate large molecules as antibiotics which inhibits pathogen proliferation [10-13]

Amoxicillin is a hydrophilic drug which appertains to penicillin group of antibiotics used to treat various types of bacterial infections [12]. Similar studies were carried out in literature [13-21]

It is considered that clavulanic acid $(C A)$ is a feasible inhibitor of $\beta$-lactamases that hydrolyze $\beta$-lactam antibiotics and lower their efficiency [22, 23].
The major goal of this work was to designe antimicrobial nanohybrids by incorporation of antibiotics into LDHs nanomaterials thus enhancing antibacterial activity of these formulations.

\section{Experimental part}

Materials and methods

Coprecipitation method was used to synthesize MgAlLDHs, where metal salts solutions were mixed together under vigorous stirring. The $\mathrm{pH}$ of the mixed solution was adjusted at the desired value of 9.5 by adding a soda solution to support simultaneous precipitation of cation hydroxides. The obtained solution was aged for 24 hours then filtered and dried at $60^{\circ} \mathrm{C}$ to obtain nanostructures with high crystallinity.

Synthesis of drug delivery nanocomposites involves anion exchange and reconstruction method.

For anion exchange route, the initial layered double hydroxides containing NO3- as interlayer anions is added to a solution containing $1 \mathrm{~g}$ amoxicillin and $0.2 \mathrm{~g}$ clavulanic acid. Nextstep consist in maintaining the obtained solution under stirring for $20 \mathrm{~h}$ at $50^{\circ} \mathrm{C}$ followed by filtration and drying at $55^{\circ} \mathrm{C}$ of final product.

Reconstruction method refers to the memory effect of some LDHs nanomaterials when heated at $550^{\circ} \mathrm{C}$ form metal oxides that are able to reconstruct the pristine structure by exposing to an aqueous solution of amoxicillin and clavulanic acid. Following steps are same as described for the other mentioned method.

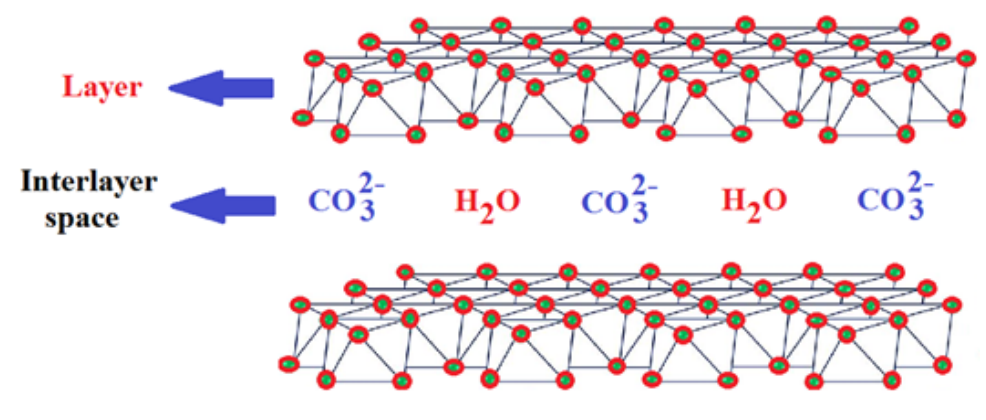

Fig. 1. LDHs-like structure

\footnotetext{
* email: letimedr@yahoo.com, getamitrea@yahoo.com
} 

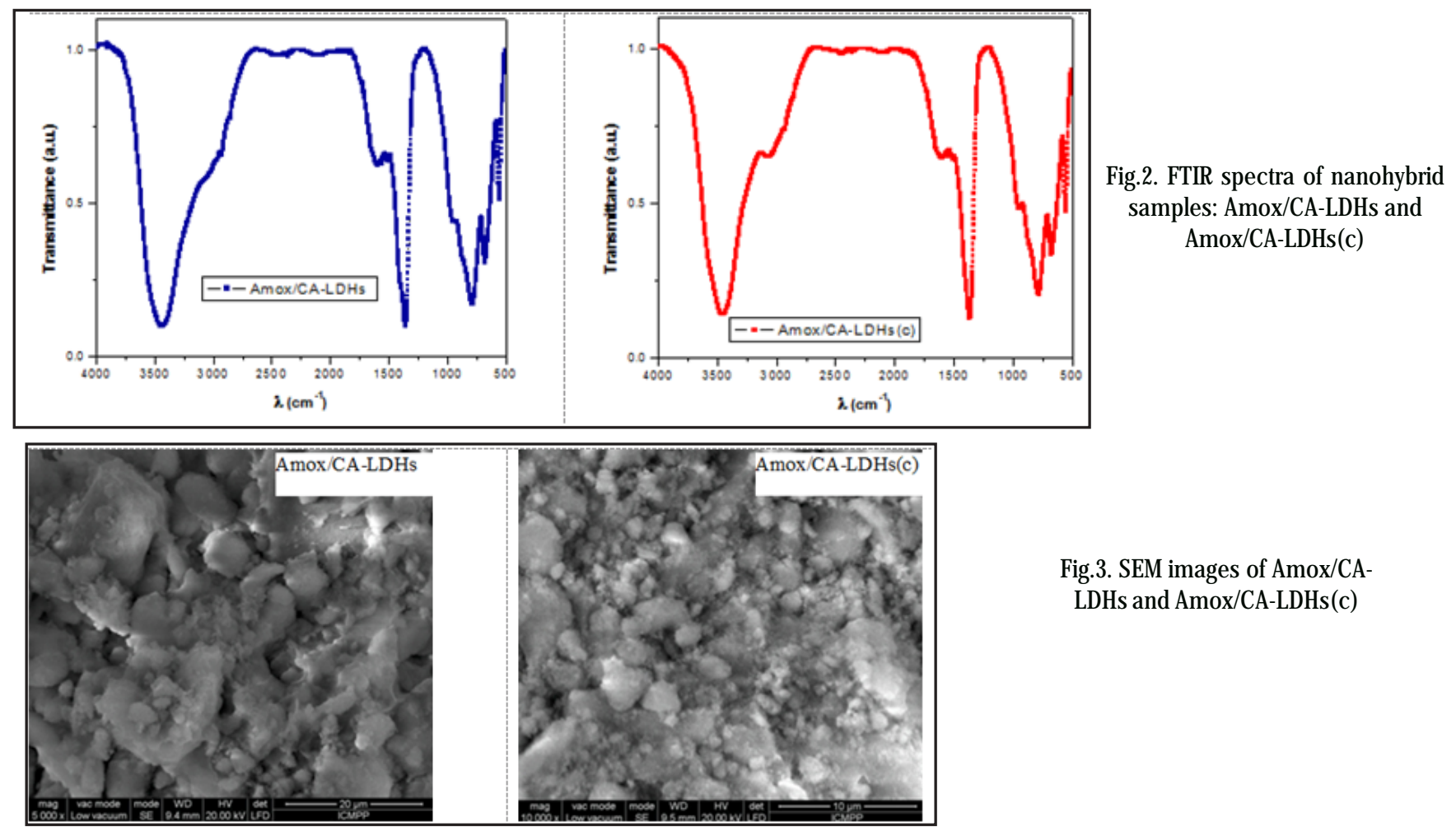

Fig.3. SEM images of Amox/CALDHs and Amox/CA-LDHs(c)

The obtained products subjected to analysis are denoted as Amox/CA-LDHs(c), for the one obtained by reconstruction method using calcined LDHs and Amox/ CA-LDHs for the nanohybrid obtained by anion exchange way. Their structural and morphological characterizations were performed using Fourier-transform infrared spectroscopy (FTIR) and Scaning electron microscopy (SEM) techniques.

\section{Results and discussions}

Figure 2 displays the IR spectra of Amox/CA-LDHs and amox/CA-LDHs(c), respectively. Both spectra show an intense and broad peak at nearly $3450 \mathrm{~cm}^{-1}$ and 3000 $\mathrm{cm}^{-1}$, corresponding to the stretching vibration of $-\mathrm{OH}$ groups of hydrotalcite layers and interlayer water molecules. The band ascribed to an asymmetric stretching vibration of carbonate anions can be observed at $1350 \mathrm{~cm}$ 1. IR bands at $1507 \mathrm{~cm}-1$ and $1595 \mathrm{~cm}^{-1}$ are attributed to characteristic stretching vibration of carboxyl groups. A strong absorption band at around $1360 \mathrm{~cm}^{-1}$ corresponds to nitrate anions. The other bands below $1000 \mathrm{~cm}-1$ refers to vibration of metal oxides bonds.

SEM images (fig. 3) reveal crystal morphologies of amoxicillin and clavulanic acid intercalated layered double hydroxides. The micrographs present a relatively narrow particle size distribution between 100 and $250 \mathrm{~nm}$ and aggregates of non-porous and compact plate-like structures which are typical for the LDHs nanoparticles and intercalated ones.

These morphology characteristics of hydrotalcites based nanocomposites indicate that drug molecules were securely intercalated into LDHs structure. Moreover, drug anions are protected by inorganic sheets and released in a controlled way being excellent reservoir of antimicrobial compounds.

\section{Conclusions}

Novel organic-inorganic nanohybrid carriers possessing beneficial properties of controlled release were synthesized. FTIR and SEM investigations revealed that amoxicillin and clavulanic acid were successfully intercalate into the LDHs nanostructure.

A major property of LDHs nanoarchitectures is their ability to incorporate different molecules as drugs with antibacterial activity and then to release the active agents in a sustained manner at the established location.

Their tendency to incorporate a variety of drugs either by anion exchange or reconstruction method, resulting in incredible nanomaterials with various applications in medical field, makes them more helpful.

\section{References}

1.RIVES, V., DEL ARCO, M., MARTíN, C, Applied Clay Science, 88-89, 2013, p. 239.

2.YASWANTH, K., RANJ ITH, K. K , CHIA-HUNG, L., Applied Clay Science, 112-113, 2015, p. 100.

3.RYU, S.J., JUNG, H., OH, J.M., LEE, J.K., CHOY, J.H., J Phys Chem Solids, 71, no. 4, 2010, p. 685.

4.HERRERO, M., LABAJ OS, F.M., RIVES, V., Appl Clay Sci, 42, no. 3-4, 2009, p. 510-518.

5.SAIFULLAH, B., HUSSEIN, M.Z., Int J Nanomedicine, 10, 2010, p. 5609.

6.BRAVO-SUAREZ, J.J., PAEZ-MOZO, E.A., OYAMA, S.T., QUIM NOVA, 27, 2004, p. 601.

7.FORANO, C., HIBINO, T., LEROUX, F., TAVIOT-GUEHO, C., Layered double hydroxides in Handbook of Clay Science, Developments in Clay Science, 2006, p. 1021.

8.BASU, D., DAS, A., STÖCKELHUBER, K.W., WAGENKNECHT, U., HEINRICH, G., Prog Polym Sci, 39, 2014, p. 594.

9.TONELLI, D., SCAVETTA, E., GIORGETTI, M., Anal Bioanal Chem, 405, 2013, p. 603.

10.ROJAS, R., PALENA, M.C., JIMENEZ-KAIRUZ, A.F., MANZO, R.H., GIACOMELLI, C.E., Appl. Clay Sci., 62-63, 2012, p. 15.

11.DUCEAC, L.D, DOBRE, C.E., PAVALEANU, I., CALIN, G., NICHITUS, S., DAMIR, D., Rev.Chim (Bucharest), 68, no. 1, 2017, p. 168.

12.SAIFULLAH, B., HUSSEIN, M.Z., Int. J. Nanomedicine, 10, 2015, p. 5609.

13.DUCEAC, L.D., STAFIE, L., BANU, E.A., PADURARU, O., CALIN, G., CIUHODARU, M. I., Rev. Chim (Bucharest), 68, no 11, 2017, p.2542. 
14.RANDAFIR, L.M., FRASINARIU, O.E., CHIRIAC, M.I., MIRON, I., Medical-Surgical J ournal-Revista Medico-Chirurgicala, 121, no. 2, 2017, p. 313.

15.DEBITA, M., MUSAT, C., MEREUTA, E., RUS, M., MEREUTA, C., FULGA, I., GANEA, D., Rev. Chim. (Bucharest), 68, no. 9, 2017, p. 2048.

16.ROMAN, I., CIORTAN, S., BIRSAN, I.G., DEBITA, M., Mat. Plast., 52 , no. 4, 2015, p. 529.

17.ROMILA, A., MOCANU, I.D., CHETRONE, M., LUNGU, M., TUTUNARU, D., CALIN, A., Acta Medica Mediterranea, 34, no. 2, 2018, p. 449.

18.TRANDAFIR, L.M., CHIRIAC, M.L., DIACONESCU, S., IONIUC, I., MIRON, I., RUSU, D., Medicine, 95, no. 44, 2016, article e5065.
19.TRANDAFIR, L.M., ANTON-PADURARU, D.T., MIRON, I., INDREI, L.L., Revista de Cercetare si Interventie Sociala, 49, 2015, p. 205. 20.DECUSARA, M., ROMILA, A., PAVEL, L., ANDREI, L.L., NEGRAIA, M.R., MACOVEI, L.A., Rev. Chim. (Bucharest), 69, no. 5, 2018, p. 1254. 21.TIUC, A.E., NEMES, O., PERHAITA, I., VERMESAN, H., GABOR, T., DAN, V., Studia Universitatis Babes-Bolyai Chemia, 60, no. 2, 2015, p. 169.

22.XU, Q., CZERNUSZKA, J.T., J. Controlled Release, 127, 2008, p. 146.

23.SAUDAGAR, P.S., SURVASE, S.A., SINGHAL, R.S., Biotechnol. AdV., 26, 2008, p. 335.

Manuscript received: 12.09 .2018 